\title{
Virtue and Manliness in Islamic Ethics
}

Recent interest in virtue ethics has led to increased interdisciplinary and interreligious lines of inquiry, moving away from a focus on Aristotelian approaches to less-studied, often non-Eurocentric ones, including the study of Asian religions (e.g., Seok 2017). In Islamic studies, research in ethics has largely centred on matters pertaining to law and meta-ethics (especially in theology), on account of a perception of Islamic virtue ethics as largely a derivation of Greek practical philosophy (e.g., Hourani 1985). Recent studies on virtue ethicsmany of which have been reviewed in this issue-have tried to bridge this gap, and for good reason: Islamic writings on the refinement of human character traits (tahdhīb al-akhlāq) often present original perspectives of great relevance for ethicists today. It is, moreover, at the meeting place of the study of gender and virtue ethics that Islamic thought displays a trajectory of development that can perhaps inform "world philosophy" more broadly. Especially in its conception of "manliness" (murüa or muruwwa) or "youngmanliness" (futu$w w a)$ as a virtue, one of particular significance to Sufism, Islamic virtue ethics captures the paradoxes of having developed a rich vocabulary of moral perfection applicable in contemporary contexts, while also doing so in ways that fix gender norms.

It is with that in mind that the articles in this special issue respond to one of three themes, tied together by an original conference on the topic of futuwwa in Doha, hosted by Hamad Bin Khalifa University's Research Center for Islamic Legislation and Ethics (CILE) in November 2019, where five of the nine authors in this collection presented earlier drafts. Those themes are (1) futuwwa ("youngmanliness" or "chivalry"), especially in premodern Sufi texts; (2) masculinity and male normativity in premodern Islamic texts, especially Sufi texts, as seen through gender critical theories; and (3) virtue ethics in classical Islamic writings, including that of Abū Ḥāmid al-Ghazālī (d. 505/1111) and Sufi authors.

Futuwwa presents a fascinating case for the relationship between norms, gender, and Islamic programs of piety. Many of the authors here take an interest in the way failure to live up to standards of renunciation qualifies as unmanly behaviour, in contrast to the behaviour of a "youngman" ( fata $)$. As the epitome of proper manly behaviour, futuwwa was something much more than merely a virtue for the specialists, that is, the spiritual elite and their trainees: It became 
a trait celebrated in Muslim fraternities, fraternities that took on heightened popularity during the Abbasid age, some of which have lasted until today. Parallel in many ways to futuwwa is the pre-Islamic Arabian value of murüa or muruwwa, that is, "manliness." Ignaz Goldziher's Muhammedanische Studien gave special consideration to this trait, as well as the changes it underwent after Islam, transforming from a mainly Bedouin value that celebrated tribal loyalty, generosity, patronage, and retaliation to an Islamic one that celebrated duty to God, renunciation of the worldly, and forgiveness (Goldziher 1966, 1:22-9). The changes in such traits from the pre-Islamic to the post-Islamic period have also been studied by Toshihiko Izutsu, who investigated ways in which conceptions of "manliness" vary depending on a culture's definition of "man" (Izutsu 2002, 27-8). The two compound virtues, futuwwa and murüa, conceived as a collection of traits that define the honourable man or young man, often resemble one another in Islamic ethical writings, even if the focus in Sufi texts is more often on futuwwa. Mohsen Zakeri has studied pre-Islamic Iranian influence on futuwwa and futuwwa brotherhoods, an often underestimated influence (Zakeri 1995). Lloyd Ridgeon and Erik Ohlander have separately described later institutional developments in futuwwa movements, which became brotherhoods parallel to and often absorbed by Sufi orders (Ridgeon 2010; Ohlander 2008).

Yet the moral dimensions of gendered-normative virtues present us with a challenge. Undoubtedly, the ideal of futuwwa appeared and became reinforced within a patriarchal social context, one inclusive of men. While futuwwa has - even if rarely — been applied to women, and while other virtues (such as modesty, or haya $\bar{a}^{\prime}$ ) have been associated with women, the virtue of futuwwa often remains in a patriarchal framework. Aside from building on the word's etymology, Sufi writings emphasise men as exemplars of futuwwa: the persons of Abraham and 'Alī ibn Abì Țālib, as well as the young men ( fitya) of the cave, whose praiseworthy conduct is narrated in Qur'ān 18:13. Stories of youngmen ( fityān) abound in Islamic sources, carrying over a theme of "great men" that one finds in Jewish and Christian writings as well, scriptural and extrascriptural, as is the case with Islam. This patriarchal theme reflects a patriarchal social context, but also bolsters it by underscoring male normativity, as can be seen in, for example, Abū 'Abd al-Raḥmān Muḥammad ibn al-Ḥusayn al-Sulamī's (d. 412/1021) Kitāb al-Futuwwa. Al-Sulamī is an interesting case, however, because of the alternative he offers for women who, while not fityān, can qualify as niswān or "female possessors-of-futuwwa," a category that al-Sulamī draws from earlier expositors of Islamic piety. These women become lauded in al-Sulamì's book Early Sufi Women (Dhikr al-Niswa al-Muta'abbidāt al-Sūfiyyāt), which points to a spiritual devotion and an ethical rigor that 
simultaneously rivals that of men and yet goes-as intimated in the treatise itself-unnoticed. Despite al-Sulamì's treatise, as Rkia Cornell has indicated, such commemorations of female piety are cases of "exceptionalism," shedding light on women infrequently and in a manner that makes male achievements all the more universal; men and their deeds serve as benchmarks for the piety of women (Cornell 1999, 66-67; Cornell 2007, 266).

From the perspective of many accounts of Sufi ethics, human perfection cannot be achieved without the traits of futuwwa and murüa. To exclude women from these traits, therefore, excludes them from human perfection itself. As Sachiko Murata has noted, the ethicist and Akbarian commentator 'Abd al-Razzāq al-Kāshānī (d. ca. 736/1335) describes murūa (muruwwwa, in his case) as a trait required for anyone who seeks to cultivate futuwwa. In turn, futuwwa is a prerequisite for sainthood (walāya) itself, which might be better translated as "intimate friendship with God," the loftiest status in most models of Sufi ethical advancement (Murata 1992, 268). It is this that brings Sa'diyya Shaikh to revisit the tradition and make a case for gender justice in Islamic ethics based on close readings of classical Sufi texts (Shaikh 2012, 82-3). Shaikh's careful analysis of Muhyī al-Dīn ibn 'Arabī's (d. 638/1240) theory of the Complete Human (al-insān al-kämil), sometimes called the "Perfect Man," reveals ways in which he included women, reaffirming their capacity for ethical completion and realised inspiration. Indeed, that capacity has-as Shaikh notes-legal implications as well, making room for women in leadership roles ritually and socially. Placing gender within a context of social circumstance, distinct from the ontological reality of the soul, Ibn 'Arabì's views - when read by Shaikh-de-gender human perfection, freeing terms such as futuwwa and even rijäl ("men") from the fetters of masculinity. In like manner, many of the authors in this issue consider ways in which contemporary Islamic virtue ethics, as an ethics of context, might look beyond gendered norms and acknowledge a more just and thus perhaps even Islamic outlook on Islamic norms. Many of Islam's most celebrated ethical writings assume male normativity and yet, simultaneously, offer insight into the human experience that remains beneficial and, in some cases, imperative.

Lastly this issue offers larger considerations of virtue ethics in premodern Islamic writings and Sufi treatises, especially that of Abū Ḥāmid al-Ghazālī. In some cases, this has involved comparative work, considering the European and American ethical traditions as well as critical theory, thereby—one might argue- actualising Alasdair MacIntyre's argument that traditions undergo selfrectification by encountering and engaging with other traditions (MacIntyre 2007 [1981], 277). In other cases, it has involved intra-traditional speculation, a consideration of Islamic ethics in light of Islamic theological and scriptural 
studies. In all cases, the articles in this last section take seriously the expanding subdiscipline of Islamic virtue ethics, as do many of the articles in the sections preceding them. The contents of the articles can be described as follows.

\section{Youngmanliness (futuwwa) in Sufi Ethics}

Mukhtar Ali investigates futuwwa within the ethical commentary tradition, by focusing on the relevant section of Khwāja 'Abdallāh Anșārīs (d. 481/1089) Manāzil al-Säiriñ ilä al-Haqq ("Waystations of the Wayfarers to the Real"), in light of a later commentary on the text by 'Abd al-Razzāq al-Kāshānī (d. ca. 736/1335). Ali takes particular interest in futuwwa as the culmination of noble character traits (makārim al-akhlāq) through a process of what he calls "spiritual warfare" ( jihād al-nafs).

Mohammed Rustom offers an overview of the Persian equivalent to futuwwa, called jawānmardī, from the perspective of the major Islamic scholar and ethicist, 'Ayn al-Quḍāt Hamadānī (d. 525/1131). Of particular interest is the manner in which the jawānmard (which Rustom translates as "chevalier," as jawānmardī is "chivalry") represents the intrepid lover of God, as contrasted with spiritual cowards, non-men, or "wimps" (nā-mardān), who lack the manliness needed to overcome the self.

My own contribution considers Muhyī al-Dīn ibn 'Arabī's interest in futuwwa during an era of institutionalisation for various futuwwa-centred fraternities. As I argue, Ibn 'Arabì's response helps us to understand the social construction of virtue as a prerogative of premodern gentility. On one hand, Ibn 'Arabï's advocacy for law-abiding young men as ethical exemplars supports this model. On the other hand, the theoretical complexity of his theory of futuwwa shows some traces of an outlaw impulse that seems to inhere within the virtue.

\section{Masculinity and Male Normativity in Premodern Islamic Ethical Texts}

Zahra Ayubi considers the study of masculinity in Islamic contexts, especially Islamic ethics, calling attention to male normativity not only as an assumption of the original texts, but of the fields that study them. Applying a gendercritical lens is not radical, she argues, but rather a corrective justified both philosophically and through careful consideration of Islam itself as an ethical tradition. Ayubi offers an overview of contemporary approaches that might remedy longstanding male-normative injustices in Islamic ethical texts. 
Rose Deighton explores the relationship in Ibn 'Ațā' Allāh's (d. 678/1309) Kitāb al-Hikam ("Book of Wisdom") between rendering masculinity normative and transcending embodiment. The imagery and symbols of Ibn 'Ațā' Allāh's ethical language centre masculinity. More important, his mode of conveying the urgency of liberation from embodiment - to the extent possible in life-is often one that relies on gendered tropes.

Brittany Landorf's article thinks through "masculine logic" as applied in the Moroccan saint Shaykh Muhammad al-Arabī ibn Ahmmad al-Darqāwī's (d. 1239/1823) Rasā̉il. Al-Darqāwī advocates controlling the body as a manner of renunciation often equated with murüa or manliness; conversely, failures in ascetic and Sufi practice become failures of masculinity, traits of the unmanly. While al-Darqāwī does take into consideration the devotion and piety of women, he nevertheless reinforces their social limits and situates them in a supporting role vis-à-vis pious men.

Yousef Casewit offers a sweeping analysis and theorisation of Abū Ḥāmid al-Ghazālī's (d. 505/1111) al-Maqșad al-asnā fì sharh māān̄̄ asmā' Allāh al-husna ("The Highest Aim in Explaining the Meanings of God's Most Beautiful Names"). Casewit takes special interest in the treatise's theological underpinnings, namely, ways in which al-Ghazālī's Ash'arism informs his careful and incredibly influential treatise on Sufi ethics. Complexity in the concept of takhalluq bi-akhlāq Allāh (taking on the traits of God) lies not merely in the difference between Lord and servant, but between Named, name, and the servant realising that name in his or her character. This leads Casewit to explore al-Ghazālī's negotiation of theological, philosophical, and Sufi positions in constructing his treatise.

Loumia Ferhat examines what it might mean for the heart to be a locus of inspiration in the thought of Abū Ḥāmid al-Ghazālī. By considering perception, the senses, and psychology in al-Ghazâlì's writings, Ferhat posits that, in many ways, al-Ghazālì's ethics is an aesthetic matter. His writings aim to foster a sense of illumination that ceases to be a passing state and becomes, instead, a lasting ethical quality, or, one might say, virtue.

Atif Khalil argues that humility can be considered a "metavirtue" in Islamic thought. Humility in various forms (particularly khushū' and tawādu) serves as a principal character trait in the Qurān, the Hadīth, and, especially, the Sufi ethical tradition. In contradistinction to it are forms of pride that result in a person's ethical ruin. Khalil argues that humility, as a virtue, lies between 
extremes; it is subject to deficiencies and excesses: pride and related vices, on one hand, and self-denigration and related vices, on the other.

Finally, in terms of a reconsideration of Islamic virtue ethics relevant to the topics herein, I recommend to the reader five recent titles, three by authors included in this special issue: Zahra Ayubi's Gendered Morality: Classical Islamic Ethics of the Self, Family, and Society (New York: Columbia University Press, 2019); Atif Khalil's Repentance and the Return to God: Tawba in Early Sufism (Albany, New York: State University of New York Press, 2018); and Cyrus Ali Zargar's The Polished Mirror: Storytelling and the Pursuit of Virtue in Islamic Philosophy and Sufism (London: Oneworld, 2017). Ayubi's and Khalil's monographs are reviewed in this issue, by Samuel Kigar and Muhammad U. Faruque, respectively. Two other titles relevant to Islamic virtue ethics are also reviewed in this issue, namely, Sophia Vasalou's Virtues of Greatness in the Arabic Tradition (Oxford: Oxford University Press, 2019), and Ethics and Spirituality in Islam: Sufi Adab (Leiden: Brill, 2017), edited by Francesco Chiabotti, Ève Feuillebois-Pierunek, Catherine Mayeur-Jaouen, and Luca Patrizi. Those are reviewed by Syed Maisam Haider Ali Rizvi and Atif Khalil, respectively.

This issue presents the work of an international group of writers and editors, such that the use throughout of British spelling and American punctuation represents a compromise. The transliteration style is that of the International Journal of Middle East Studies, except that consonants shared by Arabic and Persian have been transliterated with Arabic consonant equivalents. My gratitude goes to all those who contributed to this special issue, authors, reviewers, and editors, especially Abdurraouf Oueslati, without whose tireless efforts an issue of this size would not have been possible.

\author{
Cyrus Ali Zargar \\ Al-Ghazali Distinguished Professor, Department of Philosophy, \\ University of Central Florida, Orlando, FL, USA \\ zargar@ucf.edu
}

\title{
Bibliography
}

Ayubi, Zahra. 2019. Gendered Morality: Classical Islamic Ethics of the Self, Family, and Society. New York: Columbia University Press.

Chiabotti, Francesco, Ève Feuillebois-Pierunek, Catherine Mayeur-Jaouen, and Luca Patrizi, eds. 2017. Ethics and Spirituality in Islam: Sufi Adab. Leiden: Brill.

Cornell, Rkia. 2007. 'Soul of a Woman Was Created Below': Woman as the Lower Soul (Nafs) in Islam." In World Religions and Evil:Religious and Philosophical Perspectives, edited by Hendrik M. Vroom, 257-280. New York: Rodopi. 
Cornell, Rkia. 1999. “Introduction.” In Early Sufi Women (Dhikr an-Niswa al-Muta'abbidāt aṣ-Șüfyyāt), by Muhammad ibn al-Ḥusayn al-Sulamī, edited and translated with introductions and notes by Rkia Elaroui Cornell, 15-70. Louisville, KY: Fons Vitae.

Goldziher, Ignaz. 1966. Muslim Studies (Muhammedanische Studien), edited by S. M. Stern, translated by C. R. Barber and S. M. Stern. London: George Allen and Unwin Ltd.

Hourani, George F. 1985. Reason and Tradition in Islamic Ethics. Cambridge, UK: Cambridge University Press.

Izutsu, Toshihiko. 2002. Ethico-Religious Concepts in the Qur'ān. Montreal and Kingston: McGill-Queen's University Press.

Khalil, Atif. 2018. Repentance and the Return to God: Tawba in Early Sufism. Albany, New York: State University of New York Press.

MacIntyre, Alasdair. 2007 [1981]. After Virtue: A Study in Moral Theory, Third Edition. Notre Dame, Indiana: University of Notre Dame Press.

Murata, Sachiko. 1992. The Tao of Islam: A Sourcebook on Gender Relationships in Islamic Thought. Albany, NY: State University of New York Press.

Ohlander, Erik S. 2008. Sufism in an Age of Transition. Leiden and Boston: Brill.

Ridgeon, Lloyd. 2010. Morals and Mysticism in Persian Sufism: A history of Sufi-futuwwat in Iran. London and New York: Routledge.

Seok, Bongrae. 2017. Moral Psychology of Confucian Shame: Shame of Shamelessness. London, Lanham, Maryland: Rowman \& Littlefield International.

Shaikh, Sa'diyya. 2012. Sufi Narratives of Intimacy: Ibn Arabi, Gender, and Sexuality. Chapel Hill, NC: The University of North Carolina Press.

Vasalou, Sophia. 2019. Virtues of Greatness in the Arabic Tradition. Oxford: Oxford University Press.

Zakeri, Mohsen. 1995. Sāsānid Soldiers in Early Muslim Society: The Origins of 'Ayyārān and Futuwwa. Wiesbaden: Harrassowitz Verlag.

Zargar, Cyrus Ali. 2017. The Polished Mirror: Storytelling and the Pursuit of Virtue in Islamic Philosophy and Sufism. London: Oneworld. 